\title{
Factors Influencing Farmers' Awareness and Risk Perception of Environmental Degradation in Bangladesh
}

\author{
Airin Rahman ${ }^{1,2}$, Naiping Zhu ${ }^{1 *}$, Md Din Il Islam ${ }^{3}$, Sauda Afrin Anny ${ }^{2,4}$, \\ Mahfuza Afroj ${ }^{2}$, Md Nazirul Islam Sarker ${ }^{5 * *}$, Md Wahidul Islam ${ }^{6}$ \\ ${ }^{1}$ School of Finance and Economics, Jiangsu University, Zhenjiang 212013, P. R. China \\ ${ }^{2}$ Department of Agribusiness and Marketing, Sher-e-Bangla Agricultural University, Dhaka-1207, Bangladesh \\ ${ }^{3}$ College of Economics and Management, Northwest A\&F University, Yangling-712100, Shaanxi, P.R. China \\ ${ }^{4}$ Department of Applied Economics and Marketing, University of Reading, Reading, UK \\ ${ }^{5}$ School of Political Science and Public Administration, Neijiang Normal University, Neijiang, P.R. China \\ ${ }^{6}$ Department of Agribusiness, Atish Dipankar University of Science and Technology, Dhaka, Bangladesh
}

Received: 7 April 2021

Accepted: 17 August 2021

\begin{abstract}
Bangladesh is an agrarian-based developing economy that has recently achieved accelerated economic growth via its industrial sector. Such levels of industrial development have increased energy demands, with negative impacts not only on human health but also on agricultural land and biodiversity. These forms of environmental degradation pose risks to rice production, the main agricultural crop, due to associated declines in soil, water, and air quality. This study intends to analyze rice farmers' level of awareness and perception of the impacts of environmental degradation, and factors influencing the awareness. Primary data were collected from 300 rice producers in six districts in Bangladesh during August-September 2019 by a structured questionnaire, where agricultural arable lands have been degraded the most. A multinomial logit model has been used to explore the relationship among key factors. Farmer awareness levels varied according to age, farming experience, farm household income, adoption of inclusive agribusiness, access to extension workers, and distance from the nearest industrial zone. There was spatial heterogeneity among rice grower perceptions of the impacts of environmental degradation. Government guidance and some socio-economic factors could reshape and improve the farmer awareness levels on natural degradation, to facilitate the maintenance of farm operations and food security nationwide.
\end{abstract}

Keywords: degradation risk, land conversion, adoption practice, inclusive agribusiness, Bangladesh

\footnotetext{
*e-mail: npzhu@ujs.edu.cn

**e-mail: sarker.scu@yahoo.com
} 


\section{Introduction}

Bangladesh is experiencing economic growth through rapid industrialization and urbanization. Such transformations are associated with high degrees of environmental degradation and pollution. The recent urbanization and industrialization promotion policies of the Bangladesh government have had both positive and negative impacts $[1,2]$. The GDP of Bangladesh has been rising steadily (from $5.7 \%$ in 2010 to $8.2 \%$ in 2020) as a consequence of industrial growth. The industrial sector accounted for more than $30 \%$ of the total GDP. A corresponding increase in energy demands has further facilitated the degradation of natural environments, and biodiversity, and negative impacts on human health sustainable development [3, 4].

Bangladesh, whose economy has traditionally relied heavily on agricultural production, is already experiencing floods, soil erosion, topsoil fertility losses, and water scarcity, which all pose threats to agriculture [5], due to degradation triggered by unprecedented urbanization [6]. Bangladesh is a highly densely populated country ( 936 persons $/ \mathrm{km}^{2}$ ) with limited and fragmented arable land area [4]. It is challenging to maintain distance between industrial spaces and arable lands, which is necessary for the healthy growth of the two productive sectors in Bangladesh.

The agricultural sector of Bangladesh contributes $12.68 \%$ of the total GDP and almost $37.75 \%$ of the net workforce, which has decreases by about half over the last 20 years [7]. The progression is natural considering the greater emphasis increasingly placed on high-tech industries. Following loss of employment in the agricultural sector and land conversion, many farm laborers migrated to the industrial sector. Since farm laborers have been migrated to industrial sector due to low income, it creates shortage of farm labor that ultimately affects the food production. However, such developments pose further threats to food security throughout the nation. Bangladesh topped the global list of the most polluted countries in 2019 based on $\mathrm{PM}_{2.5}$ exposure, according to an IQAir AirVisual report [8], and Dhaka ranked as the $21^{\text {st }}$ most polluted city, according to the 2019 World Air Quality Report (Average PM2.5 was $83.3 \mu \mathrm{g} / \mathrm{m}^{3}$ ). In the Air Quality Index (AQI), a $0-50$ value is healthy, $51-100$ is moderate, $101-150$ is unhealthy for sensitive groups, $151-200$ is unhealthy, 201-300 is very unhealthy, and 301-500 is dangerous. At the local level, the AQI in Dhaka was on averaged 284 out of 500 on Nov 18,2020, with a peak of 294 [8], while Narayanganj documented a highest level (353).

Dhaka division has lost $75 \%$ of its wetlands as a consequence of the uncontrolled discharge of untreated industrial effluents over the past two decades [4]. In addition, illegal brick industries, unsanctioned plastic and glass industries, and numerous textile industries are the most widespread industries in the area, and they emit high amounts of pollutants. In addition, such industries require huge tracts of land, which are often converted from farmland, and later converted into industrial zones. According to World Bank report, the brick kiln sector in Dhaka Division alone can emit 9.8 million tons of greenhouse gases annually, with further negative impacts on land and water quality, in addition to the associated human and animal health concerns [9]. This slow but steady degradation process decreases farm output by increasing production costs and decreasing productivity [10] and causes adverse climate change. Consequently, farmers have to use more chemical fertilizers and insecticides to achieve their production expectation [11], which further increases degradation [12]. Thus, it is vital for farmers to perceive and be aware of the severity of the degradation to be able to adequately address the challenges and to facilitate sustainable agriculture [13].

Farmers' perceptions have a strong influence on their decision-making with regard to the strategies adopted to manage risks [14]. The awareness levels of farm households regarding the effects of environmental degradation on their farm operations plays a key role in their capacity to cope with the effects [15-17]. In addition, awareness levels regarding farmland soil, air, and water quality degradation could enable the implementation of environmentally friendly practices in farms [18] and participation in agri-environmental schemes [19]. Farmer risk perception and adoption of particular management strategies are interlinked, and several previous empirical studies have been conducted to assess the factors inducing decision-making of farmers globally [17, 20-22].

Researchers in Bangladesh have largely investigated farmer adaptation strategies in drought and flood prone areas [23-26]. One study investigated farmer responses to the financial risks following environmental degradation in locations in Bangladesh [22]. However, to the best of our knowledge, and no previous study has explored the potential influence of farmer level of awareness and risk perception on local adaptation strategies in Bangladesh, particularly in areas under threat of degradation in the wake of increasing industrialization and urbanization activities.

In the present study, we sample farmers from areas in Bangladesh where the levels of degradation are the most severe, and which was critical for both economic development and food security in the country. The study mainly intends to assess to analyze rice farmers' level of awareness and perception of the impacts of environmental degradation, and factors influencing the awareness. The results of the present study could facilitate the development of a database to support future policy development following regular monitoring of trends with regard to environmental status awareness, risk perception, and factors influencing them across populations. Furthermore, the results could provide indicators that could facilitate the understanding of local land, soil, and water quality deterioration status, which can further help policymakers to formulate 
laws to regulate the unsustainable growth of industries and urban centers near agricultural land, and the formulation of appropriate risk management and adaptation strategies.

\section{Materials and Methods}

\section{Study Area and Sampling}

A household survey was carried out in the study area, greater Dhaka Division, to collect primary data. In August-September 2019, the selected study team members (1 PhD student, 2 Master students, and 1 junior scientist from the "Krishi Gobeshona Foundation") collected data from the respondents through a multistage sampling method. Dhaka division was selected purposively due to its characteristics and data availability related to the study. Soil degradation, water lodging, water contamination, and deforestation are the severe problems faced in the area as a result of unsanctioned high-rise construction following the filling of wetlands [22], and degradation of the "Bhawal Garh" forest area (The Southern extension of the "Madhupur Tract"). Some areas in the division, which have been key rice production areas in the past, have been converted into industrial zones over the last decade.
Although not all the arable lands have been converted into industrial zones, the relatively high levels of pollution associated with the industries nearby accelerate their transformation into wastelands. In addition, many farmers and farm laborers have abandoned agriculture for industrial jobs because of the dwindling opportunities in the agriculture sector.

Most of the farmers $(>50 \%)$ that are continuing farm operations in the area have taken loans from various NGOs to boost production and support other associated costs. The concurrent labour migration and low productivity contexts pose major threats to the overall rice production and food security in the country [14]. The farmers that maintain their agricultural activities have to contend with the increasing production costs, declining yield, and decreased returns. Therefore, the selection of Dhaka division as the study area is appropriate for the present study. In the second stage, six major districts such as Tangail, Manikganj, Gazipur, Narshingdi, Narayanganj, and Munshiganj were selected for the representativeness of the study (Fig. 1).

The researchers then selected six villages purposively from each Sadar Upazilla of the selected six districts due to the levels of farmer concentration in each district. A total of 300 farm households (50 from each Sadar Upazilla) involved in rice farming were randomly selected. The following equation was used to

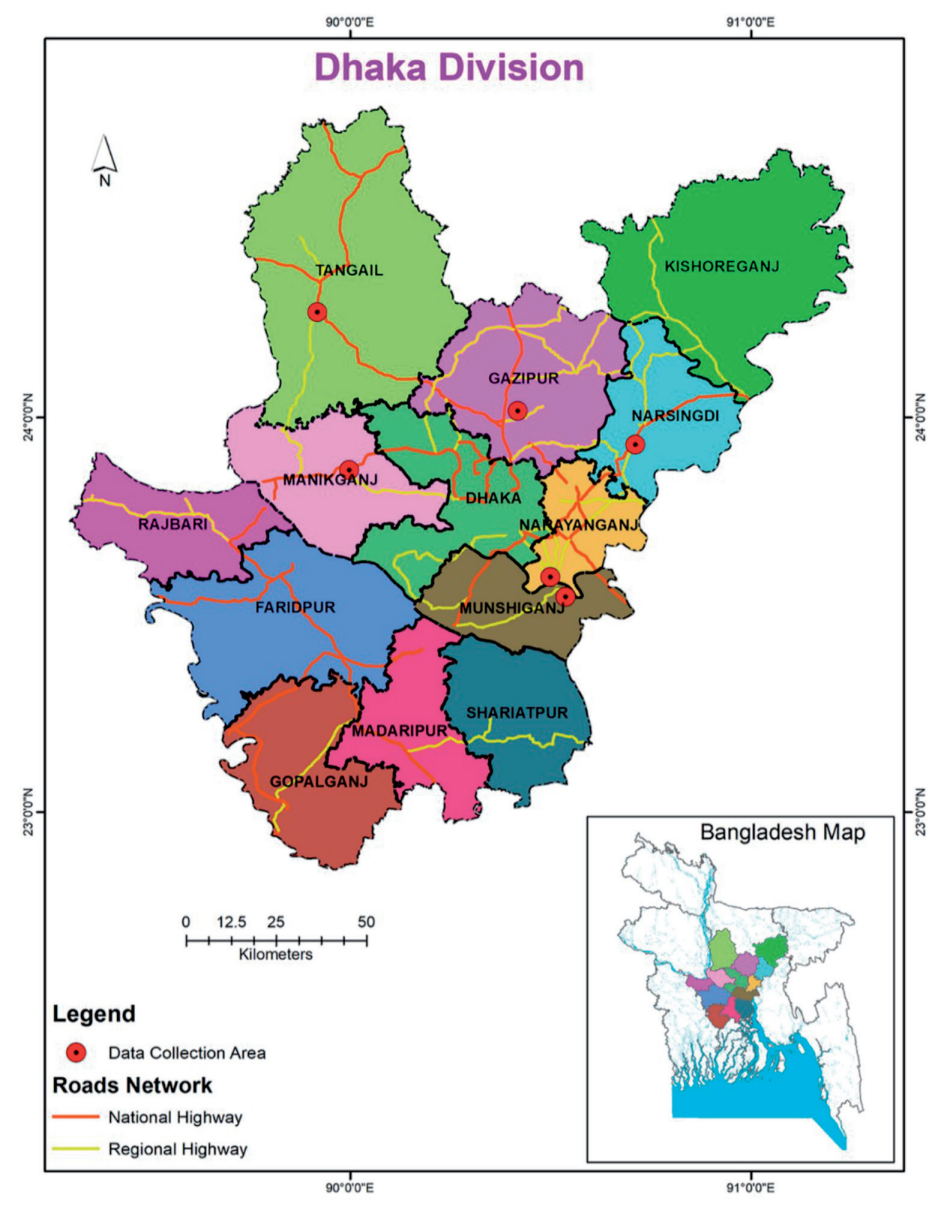

Fig. 1. Study areas under division, Bangladesh. 
determine the appropriate sample size, as suggested by Ullah et al. [27] and Akhtar et al. [28].

$$
n=\frac{N}{1+N e^{2}}
$$

Where, $\mathrm{n}$ is the sample size in each Sadar Upazilla (main district), $\mathrm{N}$ is the total number of respondents. It is noted that all respondents were agricultural credit borrowers which was the basis for selecting them for the study; e = precision at $15 \%(0.15)$.

\section{Dependent and Independent Variables}

\section{Awareness Level as Dependent Variable}

Farmer awareness levels on environmental issues was assessed based on their knowledge of the hostile impacts of pollution or degradation on their farmlands. Farmers were asked 10 questions which are presented in the supplementary Table (Table S1) and every respondent was requested to mention their level of awareness regarding the subjects on a three-point scale $(1=$ I know the exact effects and I am very aware, 2 $=\mathrm{I}$ know little and am moderately aware, $3=\mathrm{I}$ do not know and am not aware). Each statement's total score was ranged from a minimum of one to a maximum of three. Each participant's total score was ten to thirty. Here, to categorize the participants according to their level of awareness, an Interval of standard deviation from the mean (ISDM) method was used [29]. The obtained standard deviation (SD) from the average of the total awareness score was added or subtracted. Each farmer awareness level was thus, calculated as follows: very much aware scores are above than the value of (mean+SD); moderate scores are in between the (mean $\pm \mathrm{SD})$; and no awareness is less than the value (mean - SD).

\section{Farm and Farm Household Characteristics as Independent Variables}

We selected independent variables in our study based on both previous literature and context of the study areas. The explanatory variables included respondent's age, education years, household income per year, income from crop per year, farm size, access to information, farming experience (in years), off-farm income, yield loss severity, access to extension workers, and distance from the industrial areas (in $\mathrm{km}$ ). Few variables like education, age, and farming experience were measure based on year. Farm size is calculated as the total area of land by acres. Household income and income from crop represents the average net yearly earnings of a household in USD (1 USD = BDT 84.25 at the time of data collection). The distance is calculated as kilometres $(\mathrm{km})$ from the farm gate to the industrial areas.

\section{Analytical Models}

In the present study, a multinomial logit (mlogit) model was adopted to examine the factors influencing farm household levels of awareness. SPSS Version 22.0 was used for statistical calculations and analysis. Here, based on the responses, the awareness levels were categorized. That is, (i) farmers who understood the potential adverse impacts and were aware (baseline category) $=1$, (ii) farmers who understood very little about the potential adverse impacts and were moderately aware $=2$ (iii) farmers who did not understand the potential adverse impacts and were not aware $=3$. Here, parameters can be recognized and compared to the baseline category of the dependent variable. The multinomial density for one observation is defined according to the following equation:

$$
f(y)=p_{1}^{y 1} \times \ldots \ldots \times p_{m}^{y m}=\prod_{j=1}^{m} p_{j}^{y i}
$$

The probability that an individual $i$ selects the $j t h$ alternative is $p_{i j}=p_{r}\left(y_{i}=j\right)=F_{j}\left(x_{i}, \beta\right)$. The functional form of $F_{j}$ considered such that the probabilities exist between 0 and 1 and sum over $j$ to 1 . The multinomial logit model is applied with alternative-invariant regressors. The equation for mlogit with paradox $\mathrm{x}$ is as follows:

$$
\log \left(\frac{\pi_{i}}{\pi_{j}}\right)=\propto_{i}+\beta_{j} x, j=1,2, \ldots \ldots . J-1
$$

Let $P_{i j}=$ the probability that one farmer $i$ will have jth performance

Here, $i=1,2, \ldots . .600$ and $\mathrm{j}=1,2,3$, then the two multinomial logit equations are as follows:

$$
\begin{gathered}
\log \left(\frac{p\left(y_{i}=2 \mid x_{i} \text { Age }+\cdots+x_{i} \text { distance }\right)}{p\left(y_{i}=1 \mid x_{i} \text { Age }+\cdots+x_{i} \text { distance }\right)}\right) \\
=\beta_{0}+\beta_{1} x_{i} \text { Age }+\cdots+\beta_{11} x_{i} \text { distance } \\
\log \left(\frac{p\left(y_{i}=3 \mid x_{i} \text { Age }+\cdots+x_{i} \text { distance }\right)}{p\left(y_{i}=1 \mid x_{i} \text { Age }+\cdots+x_{i} \text { distance }\right)}\right) \\
=\beta_{0}+\beta_{1} x_{i} \text { Age }+\cdots+\beta_{11} x_{i} \text { distance }
\end{gathered}
$$

The variance inflation factor (VIF) was calculated to determine whether any multicollinearity in the independent variables exist. The estimated results range from 1.39 to 2.07 ( $>5$ shows high multicollinearity), indicating moderate correlation among variables in the model, that is not sufficient to need attention and may not influence on the significance of coefficients (Akinwande et al., 2015; O’ Brien, 2007). The VIF was computed using the following equation:

$$
\mathrm{VIF}=\frac{1}{1-R_{i}^{2}}
$$


Table 1. Farmer awareness levels regarding potential adverse impacts of environmental degradation on farmland.

\begin{tabular}{|c|c|c|}
\hline Awareness level & Frequency & Proportion \\
\hline $\begin{array}{c}\text { I know the adversity exactly \& } \\
\text { aware }\end{array}$ & 135 & $45 \%$ \\
\hline I know very little and not aware & 102 & $34 \%$ \\
\hline I do not know and not aware & 63 & $21 \%$ \\
\hline
\end{tabular}

Source: Authors calculation based on collected data, 2019

\section{Results and Discussion}

\section{Descriptive Statistics}

The frequencies and distributions of farmer awareness levels on the potential adverse impacts of environmental degradation on farmland have been presented in Table 1. The analysis indicates that most farmers know the danger of environmental degradation and are aware $(45 \%)$. The lowest number of farmers (21\%) scored no awareness level, while $34 \%$ of them shows moderate awareness level. Farmers had an average age of 40 years, with a three-year education on average. Respondents in the study area had an average annual income of USD 3800, where; income per year from the crop was USD 2000 on average, which is approximately $53 \%$ of the net family annual income. Forty percent of all the farmers had off-farm income sources and have an average of seven years of farming experience.

The descriptive statistics of the dependent and independent variables used in the study are presented in Table 2. In addition, $42 \%$ of respondents adopted inclusive agribusiness practices, and farm households had an average of two farm pieces of machinery in the study area (Table 2). Most of the farmers (57\%) considered environmental degradation to have a high impact on yield loss, and the majority (59\%) had farmland within $5 \mathrm{~km}$ of the industrial zone.

Fig. 2 illustrates farmer awareness levels based on the distances of their farms from industries. The majority $(72 \%)$ of the farmers, who had farmlands at distances greater than $5 \mathrm{~km}$ from industries, fell into the "not aware" group. Such groups of farmers encounter relatively less impact of degradation on agricultural activities compared to farmers undertaking agricultural activities near industries $(0.5-2.5 \mathrm{~km}$ and $2.6-5 \mathrm{~km})$, who were highly aware (81\% and $78 \%$ ).

By the statistics shown in Fig. 3, a massive proportion of farmers (52\%) fell into the "not aware" category who can only do their signature and never attended any school. Again, farmers with high education level (bachelor/above degree) are the minimum in number $(3 \%)$ who are not concerned about this issue. This finding again proves the importance of education.

Fig. 4 represents that many small farmers (52\%) are not aware of the adverse impacts of environmental degradation and suitable adoption strategies.

Table 2. Demographic characteristics of the rice farmers.

\begin{tabular}{|c|c|c|c|c|}
\hline Variable & Description of the variables & Observation & Mean & Std. Dev. \\
\hline Aware State & Awareness level of the farmer & 300 & 2.90 & 0.80 \\
\hline Age & Farmer's age & 300 & 40.10 & 14.21 \\
\hline Education Level & Number of years of schooling & 300 & 3.11 & 1.92 \\
\hline Family income & $\begin{array}{l}\text { Yearly average income of the farming family in USD } \\
\text { (USD } 1=\text { BDT } 84.25 \text { at the time of analysis) }\end{array}$ & 300 & 3800 & 2318 \\
\hline Income from crop & $\begin{array}{l}\text { Yearly average income of the farming family in USD } \\
\text { (USD } 1=\text { BDT } 84.25 \text { at the time of analysis) }\end{array}$ & 300 & 2000 & 1220 \\
\hline Off farm income status & $\begin{array}{c}\text { Dummy coded } 1 \text { if yes (farmer adopted off-farm income } \\
\text { sources), } 0 \text { otherwise }\end{array}$ & 300 & 0.40 & 0.49 \\
\hline Experience & Farming experience in year & 300 & 12.01 & 3.12 \\
\hline $\begin{array}{l}\text { Adoption of Inclusive } \\
\text { agribusiness status }\end{array}$ & Dummy coded 1 if yes, 0 otherwise & 300 & 0.42 & 0.47 \\
\hline Access to modern technologies & $\begin{array}{c}\text { Access to modern technologies in farming. Dummy coded } \\
1 \text { if high (above } 3 \text { machinery), } 0 \text { otherwise }\end{array}$ & 300 & 2.11 & 0.57 \\
\hline Easy access to extension contacts & Dummy coded 1 if yes, 0 otherwise & 300 & 0.69 & 0.41 \\
\hline Impact on farm yield loss & Dummy coded 1 if high yield loss, 0 otherwise & 300 & 0.57 & 0.50 \\
\hline $\begin{array}{l}\text { Distance from the industrial } \\
\text { areas }\end{array}$ & $\begin{array}{c}\text { Dummy coded } 1 \text { if distance within } 5 \mathrm{~km} \text { (farmland } \\
\text { exists less than } 5 \mathrm{~km} \text { of the industrial zone assumes short } \\
\text { distance), } 0 \text { otherwise }\end{array}$ & 300 & 0.59 & 0.51 \\
\hline
\end{tabular}

Source: Field survey, 2019 


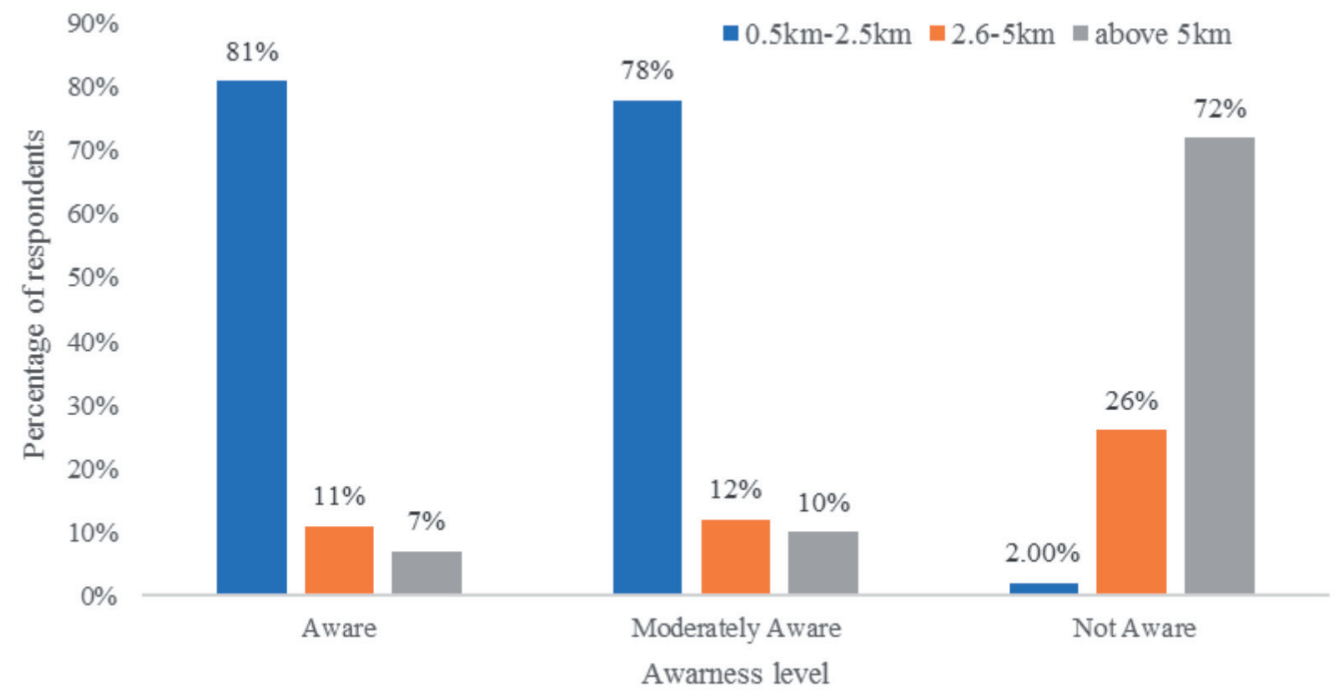

Fig. 2. Farmer level of awareness according to the distance from industrial areas.

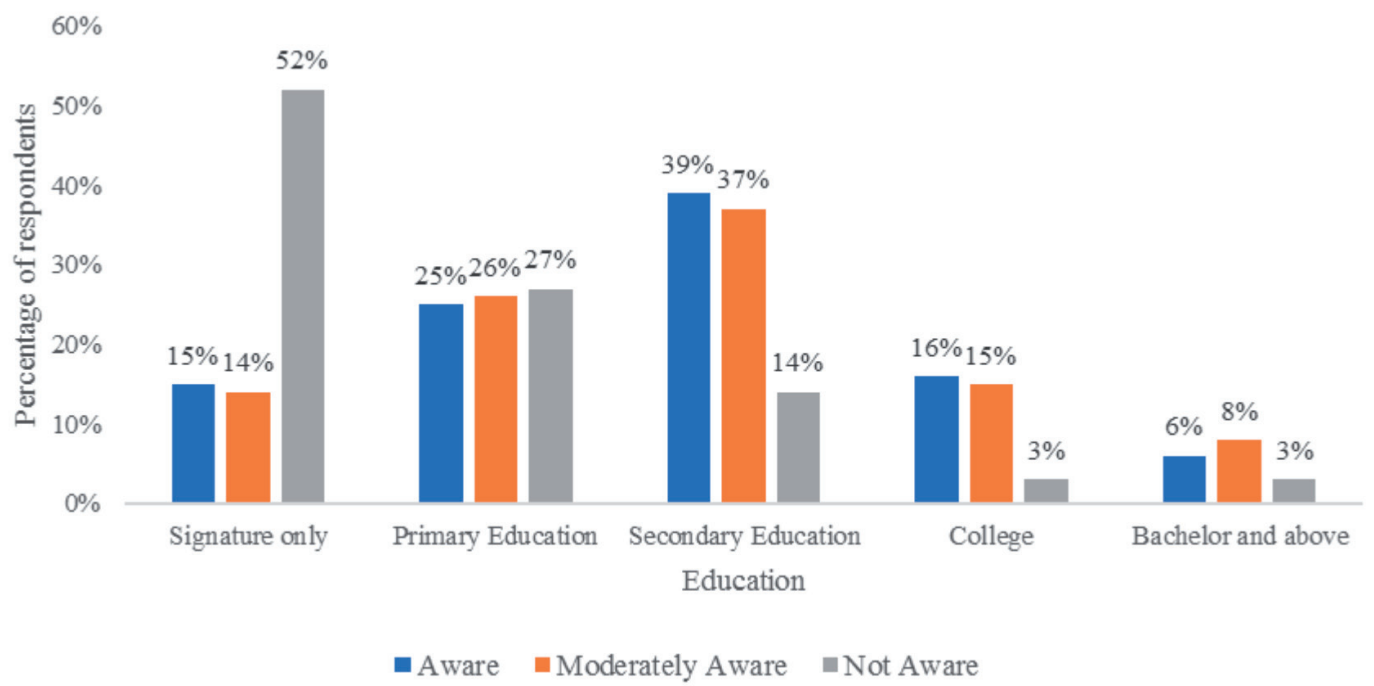

Fig. 3. Farmer level of awareness according to education level.

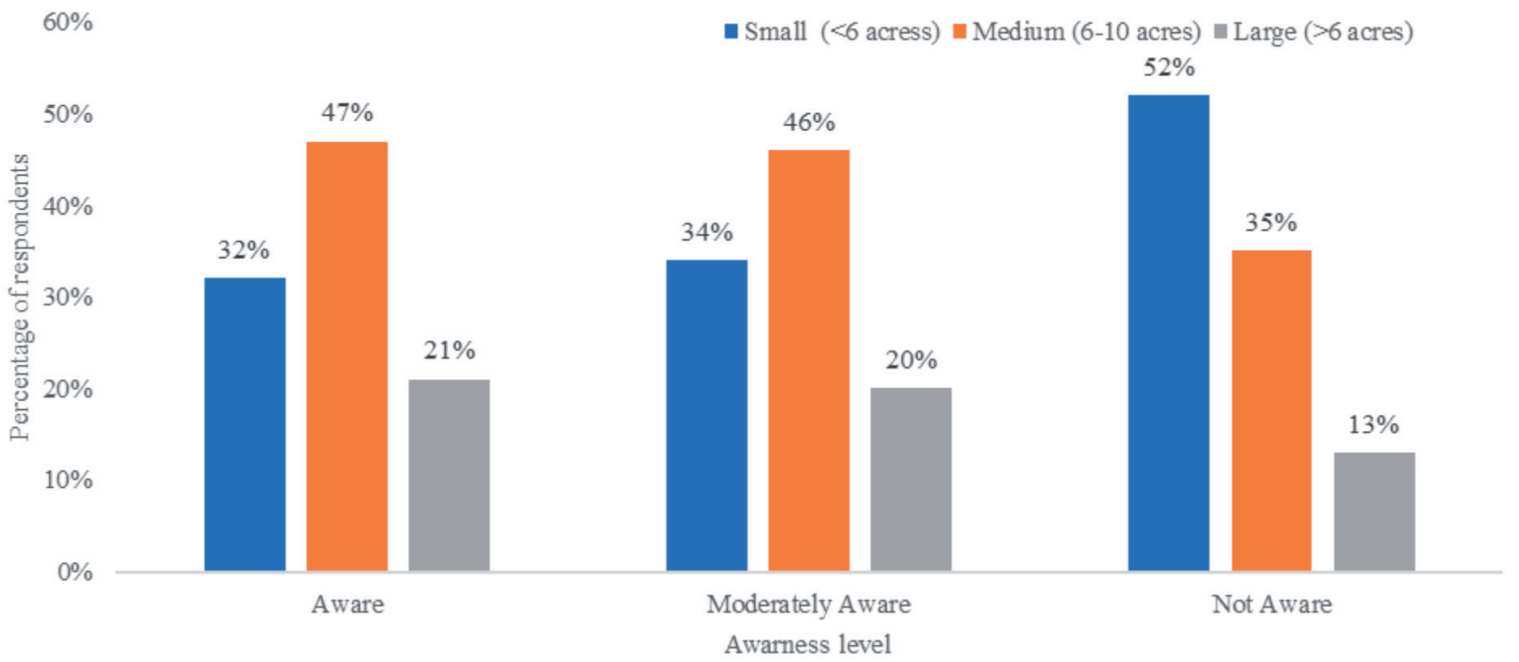

Fig. 4. Farmer level of awareness according to farm size. 
The maximum number of medium-size farmers (47\%) shows the highest awareness in the study areas.

The large percentage of farmers $(53 \%)$ who have a high proportion of crop income to net income (76\%-100\%) belongs to a higher awareness level. Again, a major portion of farmers (57\%) belongs to the lower awareness level who have the minimum proportion of crop income to net income.

We investigated the spatial heterogeneity of risk perceptions among farmers living in different areas, and the results are presented in Fig. 6 in the supplementary Table 2 (Table S2). The agricultural activities in Gazipur, Narshingdi, and Narayanganj have to contend with the high-density textile, glass, and plastic industries across the six survey areas that have transformed the soil into infertile and compact conditions. In addition, widespread deforestation (2600 ha/year) makes the problem more severe [30], which is the reason behind the high land conversion rates in the areas. Conversely, Tangail, Munshiganj, and Manikganj districts face degradation challenges associated with urbanization and industrial growth, in the form of high-water lodging, high soil salinity, and severe soil erosion. The reason for the problem is that the major rivers in the districts are affected by the leaching of untreated chemicals into the waterways [31], as well as seasonal frequent floods in the area, which lead to extreme water lodging [32].

It is necessary to know the risk perceptions of farmers on the potential adverse effects of environmental degradation on farming activities before formulating approaches or policies to mitigatethe negative

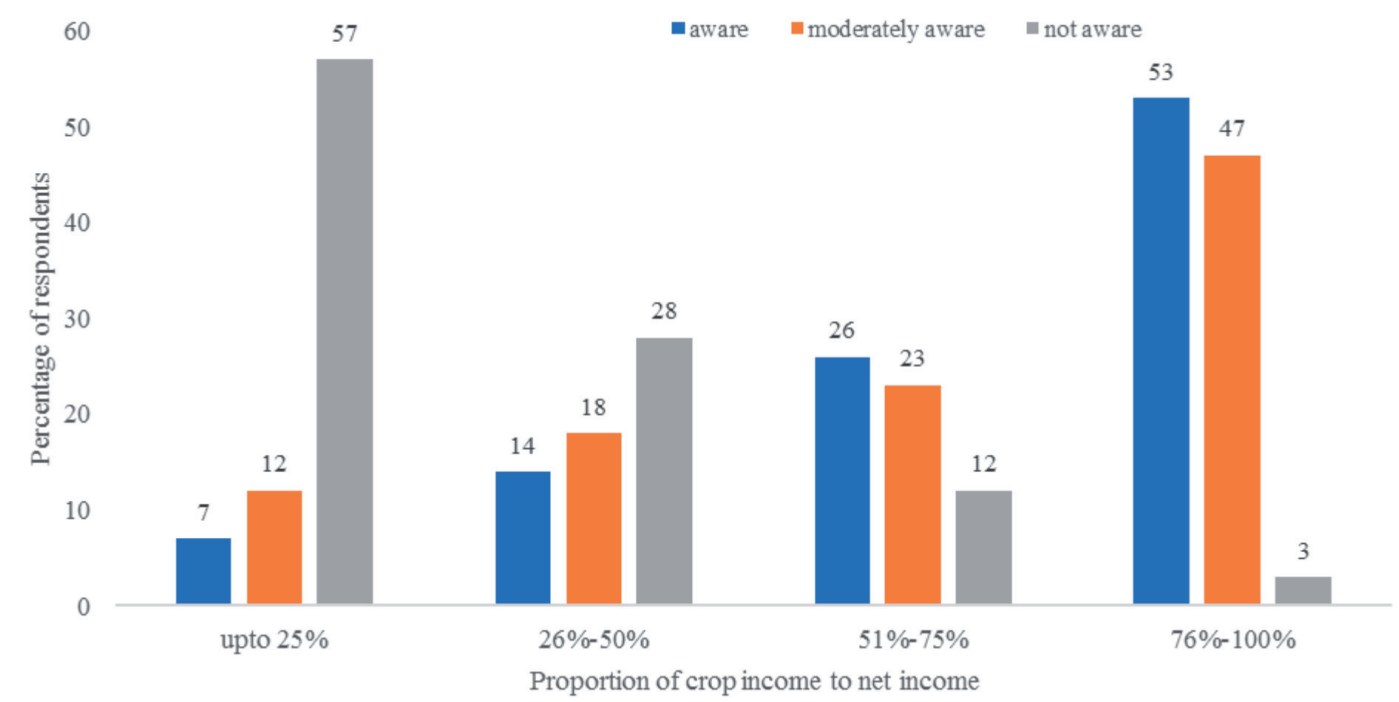

Fig. 5. Farmer level of awareness according to proportion of crop income in relation to net income/year.

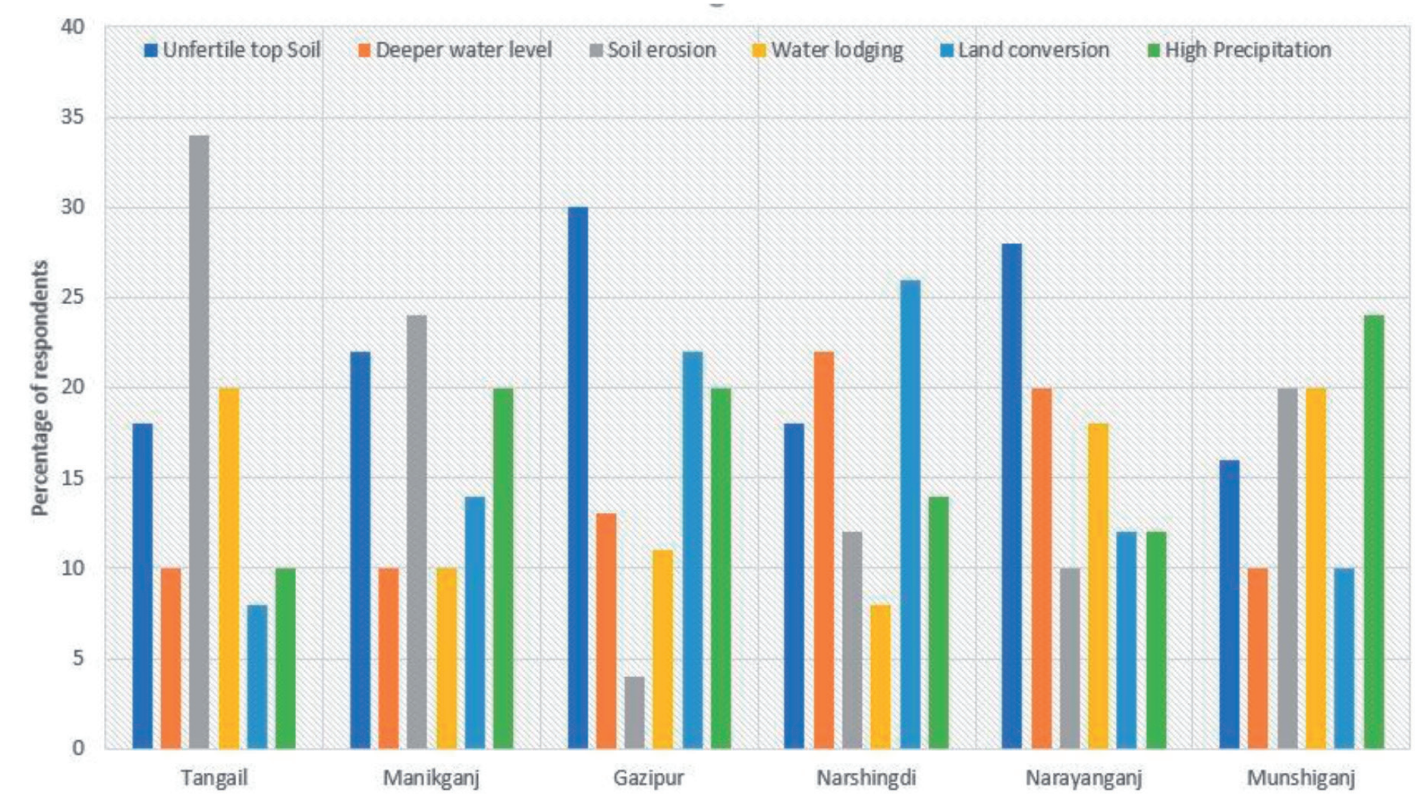

Fig. 6. Farmer risk perceptions with regard to the potential adverse effects of environmental degradation on farmland in different locations. 
Table 3. Multinomial logistic regression estimation on respondent's awareness of environmental degradation.

\begin{tabular}{|c|c|c|c|c|c|c|}
\hline Variables & $\begin{array}{l}\text { Do not know and } \\
\text { not aware }\end{array}$ & & & $\begin{array}{l}\text { Know little and } \\
\text { moderately aware }\end{array}$ & & \\
\hline & Coef. & $\mathrm{P}>\mathrm{Z}$ & $\mathrm{z}$ & Coef. & $\mathrm{P}>\mathrm{z}$ & $\mathrm{z}$ \\
\hline Age & 0.1796 & $* *$ & 1.991 & 0.1879 & $* *$ & 1.91 \\
\hline \multicolumn{7}{|l|}{ Education Level } \\
\hline Signature only & 0.6643 & & 0.041 & 0.5210 & & 0.301 \\
\hline Primary & -1.0007 & & -0.052 & -1.0081 & & -0.632 \\
\hline Secondary & -1.8819 & & -1.461 & 0.673 & & 0.131 \\
\hline College & -2.1402 & & -1.362 & 0.0437 & & 0.257 \\
\hline Bachelor \& above & -0.7976 & & -0.921 & 0.6525 & & 0.427 \\
\hline Average family income/year & -0.0002 & & -0.001 & 0.0003 & $* * *$ & 0.000 \\
\hline Income from crop & -0.0001 & & -0.012 & 0.00004 & $* * *$ & 0.0000 \\
\hline Off farm income status & 0.4121 & & 0.310 & 0.3005 & & 0.233 \\
\hline Experience & -0.9110 & $* * *$ & -3.021 & 0.1686 & $*$ & 1.843 \\
\hline $\begin{array}{l}\text { Adoption of inclusive agribusiness } \\
\text { status }\end{array}$ & -1.3150 & $* * *$ & -0.357 & -1.2610 & $* * *$ & -0.361 \\
\hline Access of modern technology & -1.0552 & & -0.892 & -1.4422 & & -1.315 \\
\hline Easy access of extension contacts & -5.8557 & $*$ & -3.421 & -4.3115 & $* *$ & -2.202 \\
\hline Impact on farm yield loss & -0.9432 & & -0.920 & -1.443 & & -1.281 \\
\hline Distance from the industrial areas & -0.8810 & $* *$ & -3.005 & -1.133 & $* * *$ & -3.600 \\
\hline
\end{tabular}

Source: Field Survey, 2019. Note: *** significant at 1\% level of confidence; **significant at 5\% level; *significant at $10 \%$ level; LR chi2 $(16)=140.87$, Prob $>$ chi2 $=0.0000$, Pseudo R2 $=0.4651$ Number of observations $=300$

impacts. Fig. 6 shows that soil fertility loss was perceived as a major challenge by farmers in Tangail (18\%), Gazipur (30\%), Manikganj (22\%), Narshingdi $(18 \%)$, and Narayanganj (28\%). However, soil erosion seems to be one of the main risks perceived by farmers in Tangail (34\%), Manikganj (24\%), and Munshiganj $(20 \%)$. In addition, high precipitation seems to be a severe problem in Manikganj (20\%), Munshiganj (24\%) and Gazipur (20\%). The risk of land conversion was a key risk perceived by respondents in Gazipur (22\%) and Narshingdi (26\%). Water lodging were highlighted as potential high risks source of environmental degradation in Tangail (20\%), Narayanganj (18\%) and Munshiganj (20\%).

\section{Determinants of Farmer's Awareness on Environmental Degradation}

According to the results, respondent age, average family income, income from the crop, farming experience, adoption of inclusive agribusiness techniques, easy access to extension services, and distance from farm to industrial zone significantly influenced farmer level of awareness. Respondent age had a significantly positively influenced awareness level ( $5 \%$ significance level), that is, awareness level on the impact of environmental degradation decreases if age increases. The values of the multinomial logistic regression analysis are listed in Table 3.

The results of age are consistent with the findings of a previous studies conducted by Alotaibi et al. [29] in Saudi Arabia and Wei et al. [33] in China. In our study area, older farmers were more comfortable engaging in off-farm income-generating activities such as tea stalls or small grocery shops that are comparatively more secure than farm businesses. Therefore, they have not considered the potential impacts of degradation on farmlands. Farmer level of education was positively correlated with awareness level, although the relationship was not significant, which is consistent with the finding of a previous study [29] but inconsistent with the observation of [34]. The results also show that farmers' awareness level has been increased with increasing level of education. Simultaneously, the level of unawareness and moderate awareness also have been decreased with increasing level of education. The values of these variables are not statistically significant. The off-farm income also shows a negative insignificant relation with awareness level. This is quite factual in the case of the scenario of our study area. The farmer who has alternative income source are much more dependent on this income, and 
they are also continuing their farm just as a family or traditional business in many cases. So, they are less interested about environmental degradation impact on farmland. Besides, the findings show that the farmers who have more technological knowledge are more aware about the impact of environmental degradation. The yield loss shows a non-significant negative relation with unawareness and moderate awareness level of the farmers. It also shows a non-significant positive relation with the awareness level indicating that the farmers who has history of losing their crop are showing more awareness about the impact of degradation on farmland.

Farming household average incomes and average incomes from crop in a year significantly positively influenced awareness level [8]. In the present study, we found that most farmers earned $53 \%$ of the family income from crop production, so that the farmers who had higher family income with higher income from farmland production had higher level of awareness (Table 3).

The results also show that farmers' farming experience positively influences their awareness level. It is inconsistent with the findings of a previous study [29]. This may occur due to differences in levels of degradation locally, and different levels of understanding under different sources of risks. Farming is a traditional business for many rural people in Bangladesh. Many of them have been engaging in farming for years and have gathered extensive experience from both their working environments and shared knowledge from older family members. Such farmers are not willing to abandon the economic activity and to apply their knowledge to mitigate the risks that arise from the emerging environmental degradation trends [35].

Farmers who are engaged in inclusive agribusiness practices exhibit high awareness, with a significantly high relationship between the two factors $(1 \%$ significance level). The concept of inclusive agribusiness is a novel practice in Bangladesh introduced by some NGOs, and not all farmers can engage in the practice due to a poor understanding of the techniques. Inclusive agribusiness is a way of linking smallholder farmers to markets by forming sustainable and mutually beneficial linkages. Such linkages provide better information, transport infrastructure, improved agricultural practices, with timely supply of better inputs, and better business prospects [36]. Naturally, farmers who have already integrated into such networks are better aware of the impact of environmental degradation on farmland.

Easy access to extension contacts has a negative relationship with farmer awareness, which is similar to the results reported in previous studies [29, 33], which further highlights how access to extension services could enhance productivity in the entire national agricultural sector via the dissemination of up-to-date information to farmers in a timely manner. However, there is still a gap between farmer communities and extension workers, considering not all farmers are aware of the increasing degradation of farmland and the potential adverse impacts [37]. Distance from industrial sites had a negative influence on awareness level which can be attributed to less exposure to adverse environmental impacts when compared to the impacts encountered by communities in areas close to industrial activities [38].

\section{Conclusions}

Farmers' levels of awareness of the impact of increasing environmental degradation on their farmlands, their perceptions of risks arise from such degradation processes, and the influencing factors have been assessed. Farmer awareness level varied across socio-economic conditions. We also observed heterogeneity in farmer awareness according to their level of knowledge on the impact of environmental degradation on farmland. The study result revealed that there is difference among farmers perception of environmental adversity based on the differences in locality. Infertile topsoil, deeper water level, soil erosion, water lodging, land conversion and high precipitation were the major effects of environmental degradation in the study areas. The results of this study have significant insinuations to save the agricultural sector in a developing country like Bangladesh. In Bangladesh, industrialization has unbalancedunplanned growth and government crop insurance program is not properly introduced. So, the findings of this study could be very helpful to improve the local farmers vulnerability by taking proper measure based on the farmers actual awareness level on degradation, their perception and some suitable adoption practices based on their level of awareness. Farmer age, offfarm income, and distance from the industrial zone negatively influenced awareness. Conversely, there were high positive correlations with explanatory variables such as farmer experience, income status, income from crop production, engagement in inclusive agribusiness, and easy access to extension services. The findings of the present study could facilitate the formulation of policies by government-level stakeholders that promote sustainable land use and agriculture in the study areas, which could further enhance productivity and food security in the nation. In addition, the findings could guide policymakers to introduce adequate governmentsupported programs that enhance farmers perceptions and awareness levels with regard to the potential impacts of increasing environmental degradation. Also, timely disbursement of adequate information and knowledge about environmental degradation will facilitate awareness among farmers. Future studies should explore farmer willingness to pay for programs aimed at minimizing the degradation of the natural environment and resources in the region. 


\section{Acknowledgement}

This study sincerely acknowledged the funding of the National social science fund of China, 2020-2024 and grant no. 20BGL099; and hosted by Professor Dr. Naiping Zhu, Jiangsu University, China.

\section{Conflict of Interest}

The authors declare no conflict of interest.

\section{References}

1. AZAM M., KHAN A.Q. Urbanization and environmental degradation: Evidence from four SAARC CountriesBangladesh, India, Pakistan, and Sri Lanka. Environ. Prog. Sustain. Energy 35, 823, 2016.

2. KHAN A., CHENGGANG Y., BANO S., HUSSAIN J. The empirical relationship between environmental degradation, economic growth, and social well-being in Belt and Road Initiative countries. Environ. Sci. Pollut. Res. 27, 30800, 2020.

3. HUANG J. Investigating the driving forces of China's carbon intensity based on a dynamic spatial model. Environ. Sci. Pollut. Res. 25, 21833, 2018.

4. RAHMAN, AIRIN JIANCHAO, LUO ADNAN, K. M. MEHEDI ISLAM, MD DIN IL ZHAO, MINJUAN SARKER, SWATI ANINDITA How indebted farmers perceive and address financial risk in environmentally degraded areas in Bangladesh. Environ. Sci. Pollut. Res. 27, 7439, 2020

5. ALAM K. Farmers' adaptation to water scarcity in drought-prone environments: A case study of Rajshahi District, Bangladesh. Agric. Water Manag. 148, 196, 2015.

6. WAN G., WANG C. Unprecedented Urbanisation in Asia and Its Impacts on the Environment. Australian Economic Review 47, 378, 2014.

7. IQAir. World's most polluted countries. 2019. World Air Quality Report, Retrieved from https:/wwwiqaircom/ world-most-polluted-countries on November 20, 2020.

8. BBS. Report on Agriculture and Rural Statistics 2018. Bangladesh Bureau Of Statistics (BBS), Dhaka, Bangladesh. pp. 1-331, 2019. Retrieved from http:// bbs.portal.gov.bd/sites/default/files/files/bbs.portal.gov. $\mathrm{bd} / \mathrm{page} / \mathrm{b} 343 \mathrm{a} 8 \mathrm{~b} 4$ _956b_45ca_872f_4cf9b2f1a6e0/ ARSSReport20052019.pdf on June 25, 2021.

9. RAHMAN M.M., TANU T.A., RAHMAN M.M., MASUDER M.R.N. Spatial Environmental Impact Degradation in Bangladesh on. Asian J. Appl. Sci. Eng. 1, 84, 2012.

10. WU J.J., FISHER M., PASCUAL U. Urbanization and the viability of local agricultural economies. Land Econ. 87, 109, 2011.

11. DADI D., AZADI, HOSSEIN SENBETA, FEYERA ABEBE, KETEMA TAHERI, FATEMEH STELLMACHER, TILL Urban sprawl and its impacts on land use change in Central Ethiopia. Urban For. Urban Green. 16, 132, 2016.

12. WU S., LIANG Z., LIU Y. Quantifying the risk of irreversible degradation for ecosystems: A probabilistic method based on Bayesian inference. Ecol. Indic. 107, 105621, 2019.
13. SINGH S. Farmers' perception of climate change and adaptation decisions: A micro-level evidence from Bundelkhand Region, India. Ecol. Indic. 116, 106475, 2020.

14. SARKER M.N.I., WU M., ALAM G.M.M., SHOUSE R.C. Life in riverine islands in Bangladesh: Local adaptation strategies of climate vulnerable riverine island dwellers for livelihood resilience. Land use policy. 94, 104574, 2020.

15. TITTONELL P., SHEPHERD K.D., VANLAUWE B., GILLER K.E. Unravelling the effects of soil and crop management on maize productivity in smallholder agricultural systems of western Kenya-An application of classification and regression tree analysis. Agric. Ecosyst. Environ. 123, 137, 2008.

16. KRUPNIK T.J., AHMED, ZIA UDDIN TIMSINA, JAGADISH SHAHJAHAN, MD KURISHI, A.S.M. ALANUZZAMAN MIAH, AZAHAR A. RAHMAN, B.M. SAIDUR GATHALA, MAHESH K. MCDONALD, ANDREW J. Forgoing the fallow in Bangladesh's stressprone coastal deltaic environments: Effect of sowing date, nitrogen, and genotype on wheat yield in farmers' fields. F. Crop. Res. 170, 7, 2015.

17. AJUANG C.O., ABUOM P.O., BOSIRE E.K., DIDA G.O., ANYONA D.N. Determinants of climate change awareness level in upper Nyakach Division, Kisumu County, Kenya. Springerplus 5, 1, 2016.

18. BOZ I. Effects of environmentally friendly agricultural land protection programs: Evidence from the Lake Seyfe area of Turkey. J. Integr. Agric. 15, 1903, 2016.

19. KRUPNIK T.J., AHMED, ZIA UDDIN TIMSINA, JAGADISH YASMIN, SAMINA HOSSAIN, FARHAD AL MAMUN, ABDULLAH MRIDHA, AMINUL ISLAM MCDONALD, ANDREW J. Untangling crop management and environmental influences on wheat yield variability in Bangladesh: An application of nonparametric approaches. Agric. Syst. 139, 166, 2015.

20. ULLAH R., SHIVAKOTI G.P. Adoption of On-Farm and Off-Farm Diversification to Manage Agricultural Risks. Outlook Agric. 43, 265, 2014.

21. ELUM Z.A., MODISE D.M., MARR A. Farmer's perception of climate change and responsive strategies in three selected provinces of South Africa. Clim. Risk Manag. 16, 246, 2017.

22. ISLAM M.D. IL, RAHMAN A., SARKER M.N.I., SARKER M.S.R., JIANCHAO L. Factors influencing rice farmers' risk attitudes and perceptions in bangladesh amid environmental and climatic issues. Polish J. Environ. Stud. 30, 177, 2021.

23. HABIBA U., SHAW R., TAKEUCHI Y. Farmer's perception and adaptation practices to cope with drought: Perspectives from Northwestern Bangladesh. Int. J. Disaster Risk Reduct. 1, 72, 2012.

24. ALAUDDIN M., SARKER M.A.R. Climate change and farm-level adaptation decisions and strategies in droughtprone and groundwater-depleted areas of Bangladesh: An empirical investigation. Ecol. Econ. 106, 204, 2014.

25. ADNAN K., YING, LIU SARKER, SWATI HAFEEZ, MUHAMMAD RAZZAQ, AMAR RAZA, MUHAMMAD Adoption of Contract Farming and Precautionary Savings to Manage the Catastrophic Risk of Maize Farming: Evidence from Bangladesh. Sustainability 11, 29, 2018.

26. ALAM G.M.M., ALAM K., MUSHTAQ S., SARKER M.N.I., HOSSAIN M. Hazards, food insecurity and human displacement in rural riverine Bangladesh: 
Implications for policy. Int. J. Disaster Risk Reduct. 43, 101364, 2020.

27. ULLAH R., JOURDAIN D., SHIVAKOTI G.P., DHAKAL S. Managing catastrophic risks in agriculture: Simultaneous adoption of diversification and precautionary savings. Int. J. Disaster Risk Reduct. 12, 268, 2015.

28. AKHTAR S., LI, GU CHENG NAZIR, ADNAN RAZZAQ, AMAR ULLAH, RAZA FAISAL, MUHAMMAD NASEER, MUHAMMAD ASAD UR REHMAN RAZA, MUHAMMAD HASEEB Maize production under risk: The simultaneous adoption of offfarm income diversification and agricultural credit to manage risk. J. Integr. Agric. 18, 460, 2019.

29. ALOTAIBI B.A., KASSEM H.S., AL-ZAIDI A., ALYAFRSI M.A. Farmers' awareness of agrienvironmental legislation in Saudi Arabia. Land use policy 99, 104902, 2020.

30. REZA A.A., HASAN M.K. Forest Biodiversity and Deforestation in Bangladesh: The Latest Update. in Forest Degradation Around the World 1-19 IntechOpen, 2020. doi:10.5772/intechopen.86242.

31. CHÈZE B., DAVID M., MARTINET V. Understanding farmers' reluctance to reduce pesticide use: A choice experiment. Ecol. Econ. 167, 106349, 2020.

32. MARTEY E., KUWORNU J.K.M. Perceptions of Climate Variability and Soil Fertility Management Choices Among Smallholder Farmers in Northern Ghana. Ecol. Econ. 180, 106870, 2021.
33. WEI Y.P., CHEN D., WHITE R.E., WILLETT I.R., EDIS R., LANGFORD J. Farmers' perception of environmental degradation and their adoption of improved management practices in Alxa, China. L. Degrad. Dev. 20, 336, 2009.

34. BAYARD B., JOLLY C.M., SHANNON D.A. The economics of adoption and management of alley cropping in Haiti. J. Environ. Manage. 84, 62, 2007.

35. HALKOS G., SKOULOUDIS A., MALESIOS C., JONES N. A Hierarchical Multilevel Approach in Assessing Factors Explaining Country-Level Climate Change Vulnerability. Sustainability 12, 4438, 2020.

36. ZHANG H., PANG Q., HUA Y., LI X., LIU K. Linking ecological red lines and public perceptions of ecosystem services to manage the ecological environment: A case study in the Fenghe River watershed of Xi'an. Ecol. Indic. 113, 106218, 2020.

37. SARKER M.N.I., WEN J., YANG B., YUSUFZADA S., HUDA N., MAHBUB F. Assessment of environmental governance in disaster vulnerability context of rural Bangladesh. Growth Change. 52, 1155, 2021. https://doi. org/10.1111/grow.12482.

38. HALKOS G., NOMIKOS S., TSILIKA K. Evidence for Novel Structures Relating CSR Reporting and Economic Welfare: Environmental Sustainability - A ContinentLevel Analysis. Comput. Econ. 2021 doi:10.1007/s10614020-10091-5.

\section{Supplementary Material}

Table S1 Measuring farmers Level of Awareness by examining their knowledge on Impacts of Environmental Degradation and adoption practices.

\begin{tabular}{|c|c|c|c|}
\hline Item & $\begin{array}{l}\text { Know exactly } \\
\text { and aware }\end{array}$ & $\begin{array}{l}\text { Know little } \\
\text { and moderately aware }\end{array}$ & $\begin{array}{l}\text { Do not know } \\
\text { and not aware }\end{array}$ \\
\hline \multicolumn{4}{|l|}{$\begin{array}{l}\text { 1. I know their might have some problem of soil compaction and am } \\
\text { remove soil compaction from my land regularly }\end{array}$} \\
\hline \multicolumn{4}{|l|}{$\begin{array}{l}\text { 2. I know the danger of discharge of untreated industrial water for my } \\
\text { crop and adopted tolerant varieties }\end{array}$} \\
\hline \multicolumn{4}{|l|}{$\begin{array}{l}\text { 3. Soil erosion is a problem from degradation and adopted to spread } \\
\text { mulch around the base of thriving plants }\end{array}$} \\
\hline \multicolumn{4}{|l|}{ 4. Topsoil fertility loss is high and I have adopted proper tillage } \\
\hline \multicolumn{4}{|l|}{$\begin{array}{l}\text { 5. Preventing my farmland from surface or groundwater pollution } \\
\text { with liquid waste by industries }\end{array}$} \\
\hline \multicolumn{4}{|l|}{$\begin{array}{l}\text { 6. I am worried about yield loss due to unfertile land and adopted } \\
\text { proper crop rotation }\end{array}$} \\
\hline \multicolumn{4}{|l|}{$\begin{array}{l}\text { 7. I have heard about the severity of soil degradation and introduced } \\
\text { earthworms by the suggestion of extension experts }\end{array}$} \\
\hline \multicolumn{4}{|l|}{$\begin{array}{l}\text { 8. I have planted anchoring plants at fallow season to keep soil } \\
\text { fertility }\end{array}$} \\
\hline \multicolumn{4}{|l|}{$\begin{array}{l}\text { 9. Farm fertility was in danger both from industrial discharges and } \\
\text { excessive pesticide use. So, I have introduced livestock farming } \\
\text { besides rice farming for securing income and much use of organic } \\
\text { manure than pesticide. }\end{array}$} \\
\hline $\begin{array}{l}\text { 10. Adopted tolerant variety as environmental degradation causes } \\
\text { yield loss }\end{array}$ & & & \\
\hline
\end{tabular}


Table S2. Farmer risk perceptions of the effects of environmental degradation on farmland in different locations.

\begin{tabular}{|c|c|c|c|c|c|c|}
\hline \multirow{2}{*}{ Sampled Area } & \multicolumn{6}{|c|}{ Variations in Perceptions (proportion \%) } \\
\hline & Unfertile topsoil & Deeper water level & Soil erosion & Water lodging & Land conversion & High Precipitation \\
\hline Tangail & 18 & 10 & 35 & 20 & 7 & 10 \\
\hline Manikganj & 22 & 10 & 25 & 10 & 13 & 20 \\
\hline Gazipur & 30 & 12 & 4 & 11 & 23 & 20 \\
\hline Narshingdi & 18 & 21 & 12 & 8 & 26 & 15 \\
\hline Narayanganj & 27 & 20 & 10 & 18 & 12 & 13 \\
\hline Munshiganj & 15 & 11 & 20 & 21 & 10 & 23 \\
\hline
\end{tabular}

